\title{
Laccase and catecholoxidase activities contribute to innate 2 immunity in slipper limpets, Crepidula fornicata

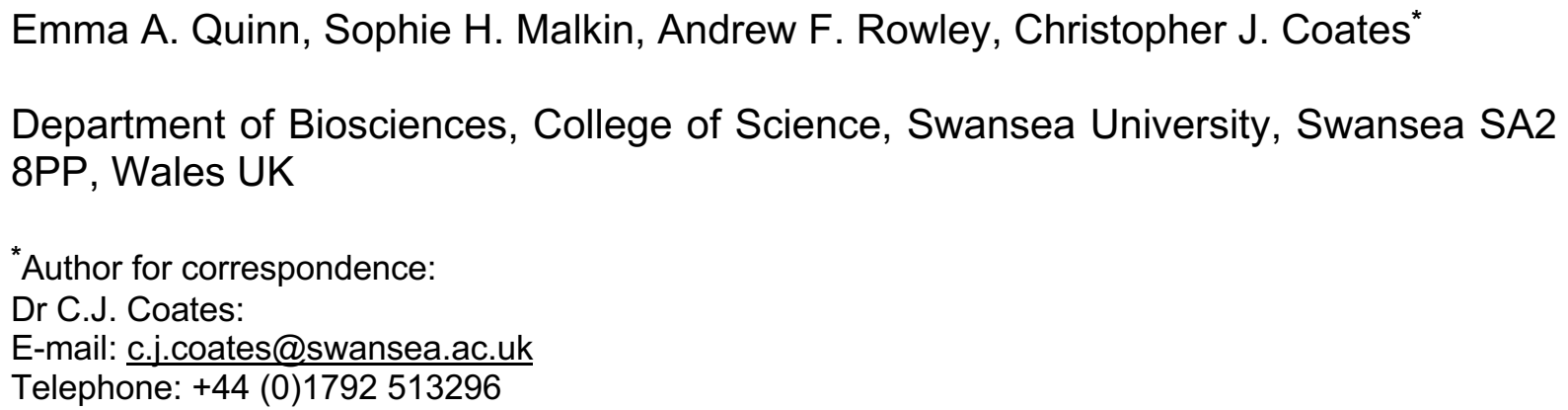

\section{Abstract}

The slipper limpet Crepidula fornicata is an invasive, non-native, marine species found throughout the coastal waters of southern England and Wales, UK. These limpets are considered to blight commercial shellfish banks, notably oysters, yet little is known about their disease-carrying capacity or their immunobiology. To address the latter, we isolated haemolymph (blood) from limpets and tested for the presence of the immune-enzyme phenoloxidase. Invertebrate phenoloxidases produce melanic polymers from simple phenolic substrates, which are deployed in the presence of pathogens because of their potent microbicidal and microbiostatic properties. We used a series of established substrates (e.g., tyrosine, hydroquinone) and inhibitors (e.g., 4-hexylresorcinol, benzoic acid) to target three distinct enzymes: laccase (paradiphenoloxidase), catecholoxidase (ortho-diphenoloxidase) and tyrosinase (monophenoloxidase). We confirmed laccase and catecholoxidase activities and characterised their kinetic properties across temperature and $\mathrm{pH}$ gradients $\left(5-70^{\circ} \mathrm{C}\right.$ and $5-10$, respectively). Crucially, we demonstrated that products derived from such laccase and catecholoxidase activities reduced significantly the numbers of colonyforming units of both Gram-positive and Gram-negative bacteria in vitro. We further screened limpet tissues for signs of melanin using wax histology, and found cells replete with eumelanin-like pigments and lipofuscin in the digestive gland, connective tissues, barrier epithelia and gills. Our data represent the first account of enzymebased antibacterial defences, notably laccase, in C. fornicata.

\section{Keywords:}

Phenoloxidase; Innate immunity; Gastropod; Melanogenesis; Invasive species; Lipofuscin; Haemocyanin 
Abbreviations:

ABTS, 2,2'-azino-bis(3-ethylbenzothiazoline-6-sulfonic acid); CO, catecholoxidase;

CTAB, Cetrimonium bromide; DHPPA, 3,5-Dihydroxyphenylpropionoic acid; L-DOPA, L-3,4-Dihydroxyphenylalanine; EDTA, ethylenediaminetetraacetic acid; 4-HA, 4hydroxyanisole; 4-HR, 4-hexylresorcinol; PO, phenoloxidase; PPD, paraPhenylenediamine; PTU, phenylthiourea; Syringaldazine, 4-Hydroxy-3,5dimethoxybenzaldehyde azine; TY, tyrosinase

\section{Introduction}

An indispensable innate immune defence strategy of invertebrates is the use of phenoloxidase (PO) enzymes in the haemolymph and solid tissues to trigger melanin synthesis (Smith and Soderhall, 1991; Cerenius et al., 2008). The catalytic steps involved in converting simple phenolic substrates (e.g., tyrosine, dopamine) into pigment precursors (quinones), and ultimately melanin, generate antimicrobial byproducts in the form of reactive oxygen/nitrogen species as well as semi-quinone intermediates (Zhao et al., 2007 and 2011; Cerenius et al., 2010a; Xing et al., 2012; Coates and Talbot, 2018). Often, the term phenoloxidase (PO) is used interchangeably to represent several distinct copper-containing enzymes: tyrosinase (EC 1.14.18.1), catecholoxidase (EC 1.10.3.1) and laccase (EC 1.10.3.2). Substrate and inhibitor specificities can be employed to discriminate between these phenoloxidases (POs). Tyrosinase catalyses the ortho-hydroxylation of monophenols (e.g., L-tyrosine) into ortho-diphenols (e.g., L-DOPA), and the two-electron oxidation of o-diphenols into o-quinones (e.g., DOPAchrome). Catecholoxidase performs the second reaction only, whereas laccase carries out the single-electron oxidation of both ortho and para-diphenols amongst other substrates (e.g., para-diamines; Reiss et al., 2013; Whitten and Coates, 2017). The differences in catalysis can be attributed to their active sites; laccase contains a mononuclear (type1) copper site as well as a trinuclear copper cluster, whereas tyrosinase and catecholoxidase contain a dinucelar (type 3) copper site (Solomon et al., 2014). Such structural features of laccase facilitate its wide catalytic potential.

Once pathogens breach the physical barriers of the exoskeleton or integument, they are recognised in the haemolymph by circulating haemocytes equipped with pathogen recognition receptors that stimulate the proteolytic, prophenoloxidase activation 
Accepted; Developmental and Comparative Immunology; $27^{\text {th }}$ April 2020.

cascade amongst other acute phase effectors (Cerenius et al., 2010b). Melanic polymers are generated and used to immobilise pathogens and facilitate their destruction - usually in concert with haemocyte encapsulation and nodulation. Beyond innate immunity, phenoloxidases contribute to developmental morphogenesis, cuticle hardening and sclerotization post-ecdysis, and assist in clot development at wound sites (haemostasis; Bidla et al., 2009; Eleftherianos and Revenis, 2011). Melaninmediated defences have been studied extensively in insects (reviewed by GonzálezSantoyo and Córdoba-Aguilar, 2012), crustaceans (reviewed by Cerenius et al., 2008), and to a lesser extent, bivalves (Zhou et al., 2012; reviewed by Luna-Acosta et al., 2017). Conversely, such experimental evidence for a proPO cascade or tyrosinase is lacking for gastropods - an exception being the well-characterised (inducible) phenoloxidase activity of the oxygen-transport protein haemocyanin (Siddiqui et al., 2006; Dolashki et al., 2011; Raynova et al., 2013; Coates and Nairn, 2014; Coates and Costa-Paiva, 2020). Like the vast majority of invertebrates studied thus far, the gastropod innate immune repertoire consists of physical barriers (exoskeleton), cellular (haemocyte) and humoral (soluble) defences (Loker, 2010). To the best of our knowledge, in-depth biochemical characterisations of gastropod phenoloxidase(s) have been performed on the commercially important abalone genus Haliotis (Le Bris et al., 2014) and medically important snail genus Biomphalaria (Le Clec'h et al., 2016). In both instances, laccase-type phenoloxidase was the dominant form of activity recorded.

The slipper limpet Crepidula fornicata (Linnaeus, 1758) is an invasive, non-native, marine gastropod in the Calyptraeidae family. It is native to the east coast of the United States of America but is now a pertinent example of an introduced species that can influence its non-native range (Orton, 1926; Cole and Baird, 1953; McNeill et al., 2010; Bohn et al., 2012). Slipper limpets were introduced accidently to European coastal waters at the end of the $19^{\text {th }}$ century, most likely with shipments of Crassostrea virginica being imported for the establishment of aquaculture (Blanchard, 1997). These limpets can be found in large numbers in most oyster production areas in England and Wales, and are implicated in having a major negative impact on native bivalves, especially the European flat oyster Ostrea edulis (Hayer et al., 2019). In shallow bays, C. fornicata can smother the sediment forming beds with several thousand individuals per $\mathrm{m}^{2}$. Dense populations of $C$. fornicata can trap suspended silt, faeces and pseudo- 
110 faeces altering the composition and structure of the seabed (Chauvaud et al., 2000).

111 Despite the sizeable volume of literature dedicated to the ecology of slipper limpets 112 and their interactions with shellfish of commercial value, there remains a paucity of

113 knowledge on their disease profiles, immunobiology or haemolymph biochemistry.

114 To address the current knowledge gap, the overall aim of this study was to examine

115 the haemolymph of $C$. fornicata for the presence of the immune enzyme, 116 phenoloxidase. First, we used a combination of general and specific substrates and 117 inhibitors to discriminate between putative phenoloxidases (monophenolase, para118 and ortho-diphenolase). Second, we assessed the antiseptic properties of enzyme119 catalysed reaction products toward Gram-positive/negative bacteria, and third, we 120 inspected limpet tissues for evidence of melanin using a histological approach.

\section{Materials and Methods}

124 All chemicals/reagents used were of the highest purity available from Sigma-Aldrich 125 (Dorset, UK) at the time of purchase.

\subsection{Experimental animals}

128 Field sampling and collection of live adult $C$. fornicata stacks (Figure 1A) took place in 129 the low intertidal zone ( 0.8-1.5m above chart datum) at Mumbles Beach, Swansea,

130 South Wales, UK (51.571882, -3.987040). Samples were returned to the laboratory 131 and processed immediately. Individuals were separated from stacks and cleaned of 132 epibionts.

\subsection{Isolation and preparation of haemolymph}

Haemolymph was isolated from the animals by first removing the tissue mass from the shell using a blunt-ended probe and allowing the haemolymph to pool in the shell cavity (Figure 1B). The haemolymph was collected using a 22-gauge hypodermic needle fitted to a $1 \mathrm{~mL}$ sterile syringe. Haemolymph samples were combined from 3 to 5 limpets per replicate and centrifuged at $1000 \times g$ for 5 min at $4^{\circ} \mathrm{C}$ to separate the

140 haemocyte fraction. The cell-free supernatant was retained, stored at $4^{\circ} \mathrm{C}$, and used in enzyme assays within $1-2$ days (no deterioration was observed for this duration). 
Accepted; Developmental and Comparative Immunology; $27^{\text {th }}$ April 2020.

\subsection{Protein determination of the haemolymph}

144 The total protein content of the C. fornicata acellular fraction of haemolymph was quantitated by the Biuret method (Gornall et al., 1949), using egg albumin (0 - $20 \mathrm{mg}$ $\mathrm{mL}^{-1}$ ) as a protein standard.

\subsection{Assay for phenoloxidase-like activities}

149 Phenoloxidase activities were assayed spectrophometrically in 96-well microplates

150 (Greiner 96-F-bottom) or $1 \mathrm{~mL}$ cuvettes using a BMG LABTECH SPECTROstar Nano 151 equipped with a cuvette port and microplate reader. Each assay consisted of $100 \mathrm{mM}$ 152 sodium phosphate (NaPi) buffer $\mathrm{pH} 7.4$ and $1 \mathrm{mgmL}^{-1}$ haemolymph protein (preincubated at room temperature $\left(\sim 20^{\circ} \mathrm{C}\right)$ for 5 minutes). Substrates were added at varying concentrations (listed in Table 1) to initiate the reaction and run for 10 minutes (initial assays with representatives from all substrate types were run for 40 minutes, but rates of product accumulation slowed after 10 minutes). All assays were performed in triplicate (three technical replicates per biological replicate) at $20^{\circ} \mathrm{C}$. Results were systematically corrected for non-enzymatic autoxidation of each substrate in the absence of cell-free haemolymph. Enzymatic activities were recorded and converted to units [U: $\mu \mathrm{mol}$ per minute per mg (protein)] using the following absorption coefficients and wavelengths: $36,000 \mathrm{M}^{-1} \mathrm{~cm}^{-1}$ for ABTS ${ }^{+}$(oxidised ABTS, A420 nm), $65,000 \mathrm{M}^{-1} \mathrm{~cm}^{-1}$ for syringaldazine ${ }^{+}$(oxidised syringaldazine, A525 nm), $1,370 \mathrm{M}^{-1} \mathrm{~cm}^{-}$ (oxidised $p$-Phenylenediamine, A520 nm), and 3,600 $\mathrm{M}^{-1} \mathrm{~cm}^{-1}$ for DOPAchrome and its derivatives (oxidised L-DOPA, dopamine and caffeic acid, A492 nm).

\subsection{Inhibition of phenoloxidase-like activities}

Assays were prepared as described above; however, haemolymph protein (1 $\mathrm{mgmL}^{-}$ $\left.{ }^{1}\right)$ was pre-incubated with an inhibitor for 5 minutes prior to the addition of substrate, either hydroquinone $(5 \mathrm{mM})$ or dopamine $(5 \mathrm{mM})$. The inhibitors benzoic acid, citric acid, cetrimonium bromide (CTAB), ethylenediaminetetraacetic acid (EDTA), 4hexylresorcinal (4-HR), and phenylthiourea (PTU) were used across the concentration range $0.1-1 \mathrm{mM}$. Each combination of substrate and inhibitor was carried out in 
Accepted; Developmental and Comparative Immunology; $27^{\text {th }}$ April 2020.

175 percentage reduction in enzymatic activity when compared to control values (i.e., 176 substrate only).

\subsection{Influence of $\mathrm{pH}$ and temperature on phenoloxidase-like activities}

179 Assay mixtures were prepared as stated above (section 2.4), with $1 \mathrm{mgmL}^{-1}$ protein, 5

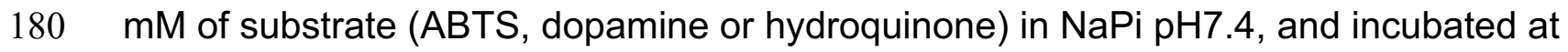
$20^{\circ} \mathrm{C}$ for 10 minutes prior to product quantification (Table 1). To find the optimum temperature of all three enzyme-ligand combinations, reactions were run between $5^{\circ} \mathrm{C}$ and $70^{\circ} \mathrm{C}$. To find the optimum $\mathrm{pH}$, the $\mathrm{NaPi}$ buffer was adjusted to values ranging from 5 to 10 (in increments of 0.5 ).

To gain insight into the haemolymph $\mathrm{pH}$ of $C$. fornicata in situ, 141 fresh limpets were collected in March 2019. Haemolymph was isolated from every animal (as described in section 2.2) and screened using Mquant $®$ Universal pH indicator strips.

\subsection{Bacterial culture and antibacterial assays}

191 Laboratory strains of Gram-positive (Bacillus megaterium, B. subtilis, Micrococcus luteus) and Gram-negative (Escherichia coli K12, Pantoea agglomerans) bacteria were sourced from Blades Biological Ltd (Kent, UK). Single colonies were picked from nutrient agar (Thermo Scientific) and cultured overnight in liquid medium at $37^{\circ} \mathrm{C}$, except $P$. agglomerans, which was grown at $30^{\circ} \mathrm{C}$. Optical density values were recorded using a V-1200 spectrophotometer. Once bacterial suspensions reached an $\mathrm{OD}_{600}$ value of 1 , cells were pelleted via centrifugation at $1000 \times \mathrm{g}$ for $5 \mathrm{~min}$ (room temperature), washed twice in $\mathrm{NaPi}$ pH 7.4, and diluted in the same buffer to yield 1 $\mathrm{x} 10^{6}$ colony forming units (CFUs) per $\mathrm{mL}$.

Upon completion of phenoloxidase assays using $5 \mathrm{mM}$ of substrate (L-DOPA, dopamine, hydroquinone), reaction volumes were centrifuged at $4000 \times \mathrm{g}$ for 5 minutes (room temperature) using Amicon Ultra Filter Units (Millipore) with a $10 \mathrm{kDa}$ molecular weight cut-off to remove any potential laccase or catecholoxidase enzymes. Reaction filtrates $(100 \mu \mathrm{L})$ were mixed with bacterial suspensions in a 1:1 ratio and incubated at room temperature for 1 hour. Following incubation, samples were diluted serially in 
at $30^{\circ} \mathrm{C}\left(P\right.$. agglomerans) or $37^{\circ} \mathrm{C}$ (all other bacteria) for $\leq 48$ hours. Control assays in the absence of substrate, and in the presence of an inhibitor (1 mM PTU), were run to attribute antibacterial activity to laccase- and catecholoxidase-derived products only.

\subsection{Histology of Crepidula fornicata soft tissues}

Whole tissue histology of $C$. fornicata was used to screen a subset $(n=10)$ for signs of tissue pigmentation, namely melanin. Intact tissues were separated from limpet shells using a blunt-ended probe, submerged in Davidson's seawater fixative (Hopwood, 1996) for 24 hours, and washed in $\mathrm{dH}_{2} \mathrm{O}$ prior to storage in $70 \%$ ethanol. Samples were dehydrated using an ethanol series, $70 \%, 80 \%$ and $90 \%$ for 1 hour each, followed by $3 \times 1$ hour in 100\% ethanol. These samples were washed twice in HistoClear/HistoChoice for 1 hour each prior to immersion in paraffin wax: HistoChoice (1:1) for 1 hour. Embedded samples were cut into sections $5-7 \mu \mathrm{m}$ in thickness (using a Leica RM2245 microtome), adhered to glass slides using egg albumin $(\sim 1 \% \mathrm{w} / \mathrm{v})$, and dried for 24 hours. Slides were stained using Cole's haematoxylin and eosin. Stained slides were inspected and imaged using an Olympus BX41 microscope.

\subsection{Data handling}

All values reported here represent the mean \pm standard error. Enzyme assays were performed in triplicate on three independent occasions. Michaelis-Menten non-linear regression and Lineweaver-Burk plots were used to calculate $K_{M}$ and $V_{\text {max }}$ values. Antibacterial assays were also performed in triplicate on three independent occasions, with data being analysed using 2-way ANOVA and Tukey's multiple comparison (posthoc) tests. Statistical differences were considered significant when $P \leq 0.05$. Data analyses and visualisations were performed in GraphPad PRISM v7. Histology images were adjusted for contrast and colour balance only.

\section{Results}

3.1 Characterising phenoloxidase-like activities in the haemolymph of Crepidula fornicata

Using a broad series of known phenoloxidase substrates, we confirmed enzymatic activity in the presence of three ortho-diphenols, one para-diphenol, two methoxy- 
containing phenols, and one non-phenolic para-diamine (Figure 2, Supplementary Figure 1). At concentrations $\leq 10 \mathrm{mM}$ for caffeic acid, dopamine and L-DOPA, $\leq 15 \mathrm{mM}$ for hydroquinone, $\leq 20 \mathrm{mM}$ for ABTS and $p$-phenylenediamine, and $\leq 50 \mathrm{mM}$ for syringaldazine, kinetic data were calculated using the Michaelis-Menten equation and Lineweaver-Burk intercepts (Table 2). Goodness of fit values $\left(R^{2}\right)$ for all regressions ranged from $0.74-0.96$. The Michaelis constant $\mathrm{K}_{\mathrm{M}}$ for all three ortho-diphenols was $<1.5 \mathrm{mM}$, with L-DOPA being the lowest at $0.26 \mathrm{mM}$, which suggests it is the preferred substrate in vivo. Hydroquinone ( $p$-diphenol) had a similarly low $\mathrm{K}_{\mathrm{M}}$ value of $2.05 \mathrm{mM}$, however, its maximum velocity $\left(\mathrm{V}_{\max }\right)$ of $\sim 4.4 \mathrm{U}$ was 3 -fold higher than L-DOPA and 1.8-fold higher than dopamine (1.4 $U$ and $2.5 \mathrm{U}$, respectively; Figure 2, Table 2). The highest $V_{\max }$ value of $5.7 \mathrm{U}$ was recorded for the exogenous substrate ABTS (a methoxy-containing phenol), but this was accompanied by the highest $\mathrm{K}_{\mathrm{M}}$ value of 21 $\mathrm{mM}$ - indicating the enzyme-ligand complex is not stable. Under our experimental conditions, we did not observe any measurable activity in the presence of three common monophenols (4-hydroxyanisole, tyramine, L-tyrosine) or a single metadiphenol (DHPPA) using concentrations from $0.1 \mathrm{mM}$ to $>25 \mathrm{mM}$. Additionally, the use of sodium dodecyl sulphate (SDS) at concentrations in excess of critical micelle formation ( $3.5 \mathrm{mM})$ did not enhance enzymatic activity of the haemolymph protein (data not presented).

Enzyme-catalysed turnover of substrates was assessed further using a series of known phenoloxidase inhibitors (Table 3). Citric acid and benzoic acid are non-specific inhibitors of PO activity, and concentrations in excess of $0.1 \mathrm{mM}$ thwarted product formation by $71-100 \%$, regardless of the substrate used. As the active sites of POs use copper to facilitate catalysis, the metal chelator EDTA decreased dopamine oxidation by $86-100 \%$ and hydroquinone oxidation by $72-100 \%$ (Table 3 ). Using the laccase-specific inhibitor CTAB, and the laccase-specific substrate hydroquinone, activity diminished by $100 \%$. However, using CTAB at the highest concentration of 1 $\mathrm{mM}$ in the presence of dopamine, did not eliminate all enzyme activity $(\sim 10 \%$ left $)-$ indicating the presence of a second phenoloxidase. Using the tyrosinase- and catecholoxidase-specific inhibitor 4-hexylresorcinol (at 0.5 and $1 \mathrm{mM}$ ), enzyme activity decreased by $>80 \%$. 4-Hexylresorcinol had little impact when hydroquinone replaced dopamine, with $90 \%$ of enzyme activity remaining intact (Table 3 ). 
274 To gain insight into endogenous conditions, we collected fresh limpets, isolated the haemolymph, and measured the $\mathrm{pH}$. Values ranged from $7-9$ with an average $\mathrm{pH}$ of $7.5 \pm 0.15(n=141)$. Following this, we selected representatives of the three substrate classes with the highest $V_{\max }$ values, ABTS (5.7 U), dopamine (2.5 U) and hydroquinone (4.4 $\mathrm{U}$; Table 2$)$, and determined activity across a $\mathrm{pH}(5-10)$ gradient in vitro (Figure 3A). Maximum levels of ABTS oxidation occurred at $\mathrm{pH} 5.5$, whereas the enzymatic turnover of dopamine and hydroquinone (into dopaminechrome and benzoquinone) were highest at $\mathrm{pH} 7$ and 8 , respectively. Subjecting the haemolymph samples to increasing temperatures from $5-70^{\circ} \mathrm{C}$, revealed temperature optima of $35^{\circ} \mathrm{C}$ for dopamine and $45^{\circ} \mathrm{C}$ for hydroquinone (Figure $3 \mathrm{~B}$ ). Under these conditions, there were no substantial differences in product formation from hydroquinone between temperatures 35 and $50^{\circ} \mathrm{C}(89-100 \%$ inclusive $)$.

\subsection{Antibacterial potency of enzymatic reaction products}

Using both ortho and para isomers of diphenols (dopamine, L-DOPA and hydroquinone) at a standardised concentration of $5 \mathrm{mM}$, we tested the antibacterial properties of their respective oxidised quinone (by)products (dopaminechrome, DOPAchrome, benzoquinone). Overall, the exposure of bacteria to these enzymederived products led to significant reductions in CFUs; $F_{(3,40)}=254.7, P<0.0001$ (Figure 4). The majority of variation within the data, $87 \%$, can be attributed to the type of substrate used. Gram-negative bacteria were sensitive to all reaction products, in particular, oxidised hydroquinone (i.e., benzoquinone) was highly effective against $P$. agglomerans - reducing CFUs by 95\%. Conversely, Gram-positive bacteria were less sensitive to reaction products, e.g., oxidised L-DOPA (i.e., DOPAchrome) led to the smallest decline of $24 \%$ when exposed to $B$. subtilis. With that said, microbial target was determined to be a significant factor $\left(\mathrm{F}_{(4,40)}=7.03, P=0.002\right)$ and accounts for $3.2 \%$ of the variation within the data. The bactericidal potency of diphenols can be

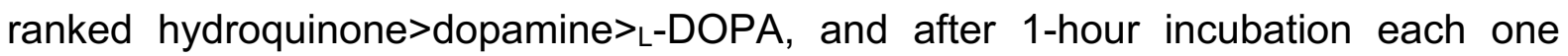
caused sufficient damage to prevent replication, immobilise and/or kill the microbes. Although the use of L-DOPA did lead to decreases in B. megaterium and $B$ subtilis CFUs, neither were significantly different to the respective controls $(P=0.099$ and $P$ = 0.335; Supplementary Figure 2). 


\subsection{Histological observations of Crepidula fornicata tissues}

Using wax (H \& E) histology, discrete brown/black pigmentation (eumelanin) was observed in the lining of the gill tissue, barrier epithelium, connective tissue, and border cells of the foot musculature (Figure 5). These melanic-deposits accumulated at the apical surface of epithelial cells (Figure 5D), but did not appear pathologic (no signs of infection or trauma). The cellular arrangement is uniform and there is no clear sign of a host response, e.g., haemocyte infiltration or encapsulation, to accompany the melanisation (which can be found in compromised tissues of invertebrates). Interestingly, yellowish pigmentation reminiscent of the lysosomal degradation product, lipofuscin, was visible in the digestive gland intra- and inter-tubular structures (Figure 5B), as well as connective tissue (Figure 5E and 5F). Lipofuscin tends to accumulate close to the nuclei of cells, which is evident here, and can sometimes appear brown due to the high levels of melanin resulting from oxidoreductase activity (Figure 5B and 5F).

\section{Discussion}

Herein, we compile strong evidence that proteins present in the acellular haemolymph of $C$. fornicata display phenoloxidase-like activities. The haemolymph tested negative for tyrosinase (monophenolase) activity and also appeared incapable of oxidising the meta-diphenol DHPPA. The low Michaelis' constant $\left(\mathrm{K}_{\mathrm{M}}\right)$ values for both laccase-type (para) and catecholoxidase-type (ortho) substrates suggested the enzyme-ligand interactions were stable (Table 2), except for the methoxy-containing phenols (syringaldazine and ABTS) with calculated values in excess of $20 \mathrm{mM}$. The oxidation of general o-diphenols (e.g., dopamine) and the more-specific p-diphenol (hydroquinone) were inhibited by the metal chelator EDTA, and in doing so, confirmed the activities to be derived from metalloenzymes - as seen in C. gigas (Luna-Acosta et al., 2010). In the presence of hydroquinone, the laccase specific inhibitor CTAB prevented all product formation. However, in the presence of dopamine, CTAB inhibited activity by a maximum of $91 \%$. Moreover, the highest concentration of the tyrosinase/catecholoxidase-specific inhibitor 4-hexylresorcinol (1 $\mathrm{mM}$ ) hindered activity by $\sim 80 \%$ and $\sim 10 \%$ in the presence of dopamine and hydroquinone, respectively (Table 3). These data endorse the presence of two independent diphenoloxidases within $C$. fornicata haemolymph, namely laccase and 
340 catecholoxidase. Regarding the aromatic amine, $p$-phenylenediamine, we obtained a $341 \mathrm{~K}_{\mathrm{M}}$ value of $2.01 \mathrm{mM}$, which is in line with those published for Biomphalaria sp., 1.19 342 to $1.45 \mathrm{mM}$ (Le Clec'h et al., 2016). Using similar assay conditions, Le Bris et al. (2014) 343 reported a much higher $\mathrm{K}_{\mathrm{M}}$ value of $13.5 \mathrm{mM}$ for Haliotis tuberculata, and Luna-Acosta 344 et al. (2011) recorded the highest at $45 \mathrm{mM}$ when studying C. gigas. We observed pH optima at 7 and 8 , and temperature optima at $35^{\circ} \mathrm{C}$ and $45^{\circ} \mathrm{C}$ in vitro for dopamine and hydroquinone, respectively (Figure 3 ). The ex vivo $\mathrm{pH}$ of $C$. fornicata haemolymph varied between 7 and 9 , which suggests it is more suited for hydroquinone oxidation (Figure 3). These data fall within the reported ranges for both laccase-type and catecholoxidase-type enzymes. For example, when using $p$-phenylenediamine, the $\mathrm{pH}$ maximum was 8.5 for Biomphalaria sp. (Le Clec'h et al., 2016), 8.2 for $H$. tuberculata (Le Bris et al., 2014), and 8.4 for Venerupis philippinarum (Le Bris et al., 2013). When using an o-diphenol, optimal activity was achieved at $\mathrm{pH} 8$ for Saccostrea glomerata (Aladaileh et al., 2007), pH 6 - 7.5 for C. virginica (Jordan and Deaton, 2005) and Chlamys farreri (Sun and Li, 1999).

Previously, Pires et al. (2000) detected three catecholamines - dopamine, L-DOPA and norepinephrine - in C. fornicata larvae and juveniles (using high performance liquid chromatography). Inhibition of tyrosine hydroxylase and dopamine- $\beta$ hydroxylase using $\alpha$-methyl-DL-m-tyrosine and diethyldithiocarbamate reduced levels of catecholamines by $20-50 \%$, and interfered with morphogenesis. Herein, we calculated low $\mathrm{K}_{\mathrm{M}}$ values $<1.5 \mathrm{mM}$ for two of the catecholamines mentioned above (Figure 2, Table 2). We posit that L-DOPA and dopamine are endogenous substrates of phenoloxidase(s) in C. fornicata adults.

Whilst bioprospecting molluscs for antiseptic compounds, Defer et al. (2009) prepared some acidic extracts of $C$. fornicata tissues and recorded antibacterial activity against M. Iuteus (Gram-positive) and Listonella anguillarum (Gram-negative), and virustatic properties toward Herpes simplex virus type 1 (viral replication was reduced by $40 \%$ when compared to the control). We also describe anti-infective properties of $C$. fornicata haemolymph (Figure 4), yet importantly, our evidence implies the mechanism of action is of enzymatic origin. The following points contend that CFU declines were due to a combination of the noxious intermediates of laccase and/or catecholoxidase 
373

374

375

376

377

378

379

380

381

382

383

384

385

386

387

388

389

390

391

392

393

394

395

396

397

398

399

400

401

402

403

404

405

406

reaction products: (1) in the absence of any substrate and in the presence of the phenoloxidase inhibitor PTU, CFU numbers were in line with controls (>97\%); (2) in the absence of haemolymph protein, no measurable antibacterial activity was observed; (3) using a $10 \mathrm{kDa}$ filter to remove potential phenoloxidase(s) from the reactions mixtures prior to microbial exposure reduced the likelihood of proteinaceous macromolecules interacting directly with the targets. The penultimate step of the eumelanin synthesis pathway is 5,6-Dihydroxyindole (DHI) formation, which can happen spontaneously or enzymatically from DOPA-derivatives, and is known to have direct antimicrobial activity (Zhao et al., 2007). DOPAchromes themselves are unstable, as are the cytotoxic oxidising and nitrosative radicals produced during phenol oxidation (Coates and Nairn, 2014).

Traditionally, laccases have not been considered part of the invertebrate innate immune system, despite their capacity to metabolise melanin precursors, i.e., phenols. First, Luna-Acosta et al. (2011) noted restricted growth $(>30 \%)$ of the marine pathogens Vibrio splendidus LGP32 and Vibrio aestuarianus 02/41 after treatment with $C$. gigas haemocyte lysate supernatant and two substrates, $p$-phenylenediamine and L-DOPA. The anti-vibrio properties were thwarted by the addition of the phenoloxidase inhibitor, PTU. Our data complement these earlier observations. The reaction products derived from hydroquinone and dopamine oxidation were highly effective against all microbes tested (Figure 4) but were indistinguishable from controls when PTU was added. In contrast, L-DOPA oxidised (by)products were not as effective against Gram-positive bacteria, notably Bacillus sp. Similar measurements were taken with regards the relatively weak antimicrobial activity of crayfish phenoloxidase and horseshoe crab haemocyanin-derived phenoloxidase when L-DOPA was used compared to other diphenols (e.g., 4-tert-butylcatechol) at the same concentration (Cerenius et al., 2010a, Coates and Talbot, 2018). Recently, Shi et al. (2017) challenged Pacific white shrimp P. vannamei with Vibrio parahaemolyticus, $M$. lysodeikticus and white spot syndrome virus (WSSV) and noted increased expression of laccase-specific mRNAs. In a separate experiment, the authors silenced the laccase gene using dsRNA, which increased shrimp susceptibility to both bacterial types, and caused $>20 \%$ higher mortality. In a subsequent study, Chen et al. (2020) identified a second laccase gene ( $L$ L Lac2) from $P$. vannamei within the epidermal layers of the carapace that was also linked to immune activity. Injection of shrimp with WSSV or $V$. 
407

408

409

410

411

412

413

414

415

416

417

418

419

420

421

422

423

424

425

426

427

428

429

430

431

432

433

434

435

436

437

439

438 The published genomes of several bivalves, C. gigas (Zhang et al., 2012), C. farreri

alginolyticus led to increased expression of the LvLac2 gene, and the oxidative stressassociated transcription factor NF-E2. Additionally, injection of dsRNA for LvLac2 reduced the survivorship of shrimp when challenged with WSSV. A notable side-effect of eliminating laccase gene expression was an increase in tissue damage found in the hepatopancreas of shrimp immune-stimulated with $\beta$-glucans. The authors concluded that it was caused by oxidative damage in the absence of laccase, and that laccase likely has multiple functions.

Phenoloxidases are distributed widely amongst metazoans, microbes and plants. Their roles differ depending on the organism, for example: plant polyphenoloxidases and arthropod tyrosinases are involved in host counter-responses to disease-causing agents, while fungal laccases act as enzymatic antioxidants/detoxicants and assist in lignocellulose degradation (Baldrian, 2006; Cerenius et al., 2008; Janusz et al., 2020). Our histological screen of $C$. fornicata solid tissues revealed the presence of melanin and lipofuscin-like pigments across diverse tissue types. In previous work by Tiley et al. (2018 and 2019), brown inclusion bodies - bulbous or conical in shape - were characterised in the digestive gland of another gastropod, the queen conch Lobatus gigas. Using a combination of techniques, including histochemical staining and electron microscopy, these were confirmed to be aggregates of melanin, iron, glycoproteins and mucopolysaccharides. In line with our observations of slipper limpet tissues, Tiely et al. $(2018,2019)$ did not find any evidence of damage, inflammation or infection (e.g., apicomplexan parasites), however, they did observe such pigmented deposits in several other areas, including ganglia. These studies may go some way to explain the presence of lipofuscin - a lysosomal degradation product in the digestive gland and connective tissues of $C$. fornicata (Figure 5). Lipochrome in the form of small yellow aggregates can be considered stage 1 lipofuscin, which can go on to form immature (stage 2) brown bodies. These brown bodies are often associated with pathogen clearance, mineral storage and cellular senescence, and the darker pigmentation can be attributed to melanin accumulation form oxidation reactions (Valembois et al., 1994). (Li et al., 2017) and Pinctada fucata martensii (Du et al., 2017), revealed major gene 
440

expansion (sub/neo-functionalisation) events for phenoloxidases, notably tyrosinases and laccases. Moreover, expression of laccase and tyrosinase-like protein mRNAs were up-regulated in regions such as the mantle and digestive gland, which further implies multiple roles in development, detoxification and defence. Interestingly, the expression of at least two laccase genes has been recorded in the epithelium, muscle, intestine, stomach, hepatopancreas, gill, haemocytes, nerve tissue and heart of penaeid shrimp (Shi et al., 2017; Chen et al., 2020).

\section{Conclusion}

We establish that enzymes present in the haemolymph of the invasive gastropod $C$. fornicata can accept diphenolic substrates and convert them into quinones (melanin precursors) in a manner similar to laccases (EC 1.10.3.2) and/or catecholoxidases (EC 1.10.3.1). The resulting (by)products are cytotoxic and possess broad-spectrum antibacterial properties. The capacity of this gastropod to generate melanin is evidenced further by the distribution of this pigment across many tissues. Taken together, we form the opinion that two constitutive phenoloxidases contribute to biological defences in $C$. fornicata.

\section{Acknowledgements}

Operations were part funded by the European Regional Development Fund through the Ireland-Wales Cooperation programme, BLUEFISH, awarded to C.J.C. and A.F.R., and Swansea University start-up funds assigned to C.J.C. A BLUEFISH innovation bursary and a College of Science (Swansea University) doctoral training grant supported E.A.Q. We should like to thank the two anonymous reviewers for their comments.

\section{Author contributions}

C.J.C. conceived and designed the experiments. All authors performed experiments and/or processed samples. E.A.Q. and C.J.C. collated and analysed data. C.J.C. drafted the text. C.J.C. revised the manuscript with input from E.A.Q., A.F.R. 
Aladaileh, S., Rodney, P., Nair, S.V., Raftos, D.A., 2007. Characterization of phenoloxidase activity in Sydney rock oysters (Saccostrea glomerata). Comp. Biochem. Physiol. B. 148(4), 470-480.

Baldrian, P., 2006. Fungal laccases-occurrence and properties. FEMS Microbiol. Rev. 30(2), 215-242.

Bidla, G., Hauling, T., Dushay, M.S., Theopold, U., 2009. Activation of insect phenoloxidase after injury: endogenous versus foreign elicitors. J. Innate Immun. 1(4), 301-308.

Blanchard, M., 1997. Spread of the slipper limpet Crepidula fornicata (L. 1758) in Europe. Current state and consequences. Scient. Mar. 61, 109-118.

Bohn, K., Richardson, C., Jenkins, S., 2012. The invasive gastropod Crepidula fornicata: reproduction and recruitment in the intertidal at its northernmost range in Wales, UK, and implications for its secondary spread. Mar. Biol. 159(9), 2091-2103.

Cerenius, L., Babu, R., Söderhäll, K., Jiravanichpaisal, P., 2010a. In vitro effects on 23.

494 Cerenius, L., Kawabata, S. I., Lee, B. L., Nonaka, M., Söderhäll, K., 2010b. Proteolytic cascades and their involvement in invertebrate immunity. Trends Biochem. Sci. 35(10), 575-583.

Cerenius, L., Lee, B. L., Söderhäll, K., 2008. The proPO-system: pros and cons for its role in invertebrate immunity. Trends Immunol. 29(6), 263-271.

Chauvaud, L., Jean, F., Ragueneau, O., Thouzeau, G., 2000. Long-term variation of the Bay of Brest ecosystem: benthic-pelagic coupling revisited. Mar. Ecol. Prog. Ser. 200, 35-48.

Chen, Y. H., Song, F., Miao, Y. T., He, H. H., Lian, Y. Y., Li, X. C., Li, M., 2020. A novel Laccase gene from Litopenaeus vannamei is involved in the immune responses to pathogen infection and oxidative stress. Dev. Comp. Immunol. 105, 103582.

Cole, H.A., Baird, R.H., 1953. The American slipper limpet (Crepidula fornicata) in Milford Haven. Nature 172(4380), 687-687.

Coates, C.J., Costa-Paiva, E.M., 2020. Multifunctional Roles of Hemocyanins. In Vertebrate and Invertebrate Respiratory Proteins, Lipoproteins and other Body Fluid Proteins (pp. 233-250). Springer, Cham.

Coates, C.J., Nairn, J., 2014. Diverse immune functions of hemocyanins. Dev. Comp. Immunol. 45(1), 43-55.

Coates, C.J., Talbot, J., 2018. Hemocyanin-derived phenoloxidase reaction products display anti-infective properties. Dev. Comp. Immunol. 86, 47-51. 
Defer, D., Bourgougnon, N., Fleury, Y., 2009. Screening for antibacterial and antiviral activities in three bivalve and two gastropod marine molluscs. Aquaculture 293(1-2), $1-7$.

Dolashki, A., Voelter, W., Dolashka, P., 2011. Phenoloxidase activity of intact and chemically modified functional unit RvH1-a from molluscan Rapana venosa hemocyanin. Comp. Biochem. Physiol. B 160(1), 1-7.

Du, X., Fan, G., Jiao, Y., Zhang, H., Guo, X., Huang, R., ... \& Wang, Z., 2017. The pearl oyster Pinctada fucata martensii genome and multi-omic analyses provide insights into biomineralization. Gigascience 6(8), gix059.

Eleftherianos, I., Revenis, C., 2011. Role and importance of phenoloxidase in insect hemostasis. J. Innate Immun. 3(1), 28-33.

González-Santoyo, I., Córdoba-Aguilar, A., 2012. Phenoloxidase: a key component of the insect immune system. Entomol. Exp. App. 142(1), 1-16.

Gornall, A. G., Bardawill, C. J., David, M. M., 1949. Determination of serum proteins by means of the biuret reaction. J. Biol. Chem. 177(2), 751-766.

Hayer, S., Bick, A., Brandt, A., Ewers-Saucedo, C., Fiege, D., Füting, S., ...Brandis, D., 2019. Coming and going-Historical distributions of the European oyster Ostrea edulis Linnaeus, 1758 and the introduced slipper limpet Crepidula fornicata Linnaeus, 1758 in the North Sea. PloS One 14(10).

Hopwood, D., 1996. Fixation and Fixatives. In: Bamcroft, J., Stevens, A., Editors. Theory and Practice of histopathological techniques (pp 23-46). Hong Kong: Churchill Livingstone.

Janusz, G., Pawlik, A., Świderska-Burek, U., Polak, J., Sulej, J., Jarosz-Wilkołazka, A., Paszczyński, A., 2020. Laccase Properties, Physiological Functions, and Evolution. Intern. J. Mol. Sci. 21(3), 966.

Jordan, P. J., \& Deaton, L. E., 2005. Characterization of phenoloxidase from Crassostrea virginica hemocytes and the effect of Perkinsus marinus on phenoloxidase activity in the hemolymph of Crassostrea virginica and Geukensia demissa. J. Shellfish Res. 24(2), 477-482.

Le Bris, C., Lepretre, M., Paillard, C., Guérard, F., 2014. Characterization of a laccaselike activity in the hemolymph of the abalone Haliotis tuberculata. Aquaculture 424, 194-200.

Le Bris, C., Paillard, C., Stiger-Pouvreau, V., Guérard, F., 2013. Laccase-like activity in the hemolymph of Venerupis philippinarum: characterization and kinetic properties. Fish Shellfish Immunol. 35(6), 1804-1812.

Le Clec'h, W., Anderson, T. J., Chevalier, F. D., 2016. Characterization of hemolymph phenoloxidase activity in two Biomphalaria snail species and impact of Schistosoma mansoni infection. Parasites Vectors 9(1), 32. 
Li, Y., Sun, X., Hu, X., Xun, X., Zhang, J., Guo, X., ...Li, J., 2017. Scallop genome reveals molecular adaptations to semi-sessile life and neurotoxins. Nat. Coomun. 8(1), 1-11.

Loker, E.S., 2010. Gastropod immunobiology. In Invertebrate Immunity (pp. 17-43). Springer, Boston, MA.

Luna-Acosta, A., Breitwieser, M., Renault, T., Thomas-Guyon, H., 2017. Recent findings on phenoloxidases in bivalves. Mar. Pollut. Bull. 122(1-2), 5-16.

Luna-Acosta, A., Rosenfeld, E., Amari, M., Fruitier-Arnaudin, I., Bustamante, P., \& Thomas-Guyon, H., 2010. First evidence of laccase activity in the Pacific oyster Crassostrea gigas. Fish Shellfish Immunol. 28(4), 719-726.

Luna-Acosta, A., Saulnier, D., Pommier, M., Haffner, P., De Decker, S., Renault, T., Thomas-Guyon, H., 2011. First evidence of a potential antibacterial activity involving a laccase-type enzyme of the phenoloxidase system in Pacific oyster Crassostrea gigas haemocytes. Fish Shellfish Immunol. 31(6), 795-800.

McNeill, G., Nunn, J., Minchin, D., 2010. The slipper limpet Crepidula fornicata Linnaeus, 1758 becomes established in Ireland. Aquat. Invasions 5(1), S21-25.

Orton, J.H., 1926. Is the American Slipper-Limpet (Crepidula fornicata) an Oyster Pest? Nature 117(2939), 304-304.

Pires, A., Guilbault, T. R., Mitten, J. V., Skiendzielewski, J. A., 2000. Catecholamines in larvae and juveniles of the prosobranch gastropod, Crepidula fornicata. Comp. Biochem. Physiol. C 127(1), 37-47.

Raynova, Y., Doumanova, L., Idakieva, K. N., 2013. Phenoloxidase activity of Helix aspersa maxima (garden snail, Gastropod) hemocyanin. Protein J. 32(8), 609-618.

Reiss, R., Ihssen, J., Richter, M., Eichhorn, E., Schilling, B., Thöny-Meyer, L., 2013. Laccase versus laccase-like multi-copper oxidase: a comparative study of similar enzymes with diverse substrate spectra. PloS One, 8(6).

Shi, L., Chan, S., Li, C., Zhang, S., 2017. Identification and characterization of a laccase from Litopenaeus vannamei involved in anti-bacterial host defense. Fish Shellfish Immunol. 66, 1-10.

Siddiqui, N. I., Akosung, R. F., Gielens, C., 2006. Location of intrinsic and inducible phenoloxidase activity in molluscan hemocyanin. Biochem. Biophys. Res. Commun. 348(3), 1138-1144.

Smith, V. J., Söderhäll, K., 1991. A comparison of phenoloxidase activity in the blood of marine invertebrates. Dev. Comp. Immunol. 15(4), 251-261.

Solomon, E. I., Heppner, D. E., Johnston, E. M., Ginsbach, J. W., Cirera, J., Qayyum, M., ...Tian, L., 2014. Copper active sites in biology. Chem. Rev. 114(7), 3659-3853. 
Accepted; Developmental and Comparative Immunology; $27^{\text {th }}$ April 2020.

621

622

623

624

625

626

627

628

629

630

631

632

633

634

635

636

637

638

639

640

641

642

643

644

645

646

647

648

649

650

651

652

653

654

655

656

657

658

659

660

661

662

663

664

665

666

667

668

Sun, H., Li, G., 1999. Phenoloxidase and myeloperoxidase activity in the haemocytes and serum of Chlamys farreri. J. Fishery Sci. China 6(2), 9-13.

Tiley, K., Dennis, M. M., Lewin-Smith, M. R., Jenkins, H. M., Kristmundsson, Á., Freeman, M. A., 2018. Digestive gland inclusion bodies in queen conch (Lobatus gigas) are non-parasitic. J. Invertebr. Pathol. 157, 4-8.

Tiley, K., Freeman, M. A., Yen, I., Dennis, M. M., 2019. Histology atlas and systematic approach to postmortem examination of the queen conch Lobatus gigas. J. Shellfish Res. 38(1), 131-148.

Xing, J., Jiang, J., Zhan, W., 2012. Phenoloxidase in the scallop Chlamys farreri: purification and antibacterial activity of its reaction products generated in vitro. Fish Shellfish Immunol. 32(1), 89-93.

Valembois, P., Seymour, J., Lassègues, M., 1994. Evidence of lipofuscin and melanin in the brown body of the earthworm Eisenia fetida andrei. Cell Tissue Res. 277(1), 183-188.

Whitten, M.M., Coates, C.J., 2017. Re-evaluation of insect melanogenesis research: Views from the dark side. Pigm. Cell Melanoma Res. 30(4), 386-401.

Zhang, G., Fang, X., Guo, X., Li, L. I., Luo, R., Xu, F., ...Xiong, Z., 2012. The oyster genome reveals stress adaptation and complexity of shell formation. Nature 490(7418), 49-54.

Zhao, P., Li, J., Wang, Y., Jiang, H., 2007. Broad-spectrum antimicrobial activity of the reactive compounds generated in vitro by Manduca sexta phenoloxidase. Insect Biochem. Mol. Biol. 37(9), 952-959.

Zhao, P., Lu, Z., Strand, M. R., Jiang, H., 2011. Antiviral, anti-parasitic, and cytotoxic effects of 5, 6-dihydroxyindole (DHI), a reactive compound generated by phenoloxidase during insect immune response. Insect Biochem. Mol. Biol. 41(9), 645652.

Zhou, Z., Ni, D., Wang, M., Wang, L., Wang, L., Shi, X., ...Song, L., 2012. The phenoloxidase activity and antibacterial function of a tyrosinase from scallop Chlamys farreri. Fish Shellfish Immunol. 33(2), 375-381. 
Accepted; Developmental and Comparative Immunology; $27^{\text {th }}$ April 2020.

669 Table 1 Substrate parameters used to discriminate between phenoloxidase activities

\begin{tabular}{lllll}
\hline Specificity & Substrate & $\begin{array}{l}\text { Molecular } \\
\text { weight }\end{array}$ & $\begin{array}{l}\text { Concentration } \\
\text { range }(\mathbf{m M})\end{array}$ & $\begin{array}{l}\text { Wavelength } \\
\text { [product detection] }\end{array}$ \\
\hline Laccase & PPD & 108.14 & $0.1-10$ & 520 \\
& Syringaldazine & 360.36 & $0.05-50$ & 525 \\
& ABTS & 548.58 & $0.01-20$ & 420 \\
\multirow{5}{*}{ Non-specific } & Hydroquinone & 110.11 & $0.1-15$ & 390 \\
& Caffeic acid & 180.16 & $1-10$ & 492 \\
& L-DOPA & 197.19 & $0.1-5$ & 492 \\
& DHPPA & 182.17 & $0.25-80$ & 492 \\
Tyrosinase & Dopamine & 189.64 & $0.1-10$ & 492 \\
& L-Tyrosine & 181.19 & $0.01-25$ & 492 \\
& 4-HA & 124.14 & $0.1-30$ & 492 \\
& Tyramine & 137.18 & $0.1-30$ & 492 \\
\hline
\end{tabular}

670

671

672

673

674

675

676

677

678

Table 2 Kinetic properties of laccase and catecholoxidase activities

\begin{tabular}{|c|c|c|c|c|c|}
\hline Substrate & Substrate class & Enzyme & $\begin{array}{l}\mathbf{K}_{\mathbf{M}} \\
(\mathrm{mM})\end{array}$ & $\begin{array}{l}\mathbf{V}_{\max } \\
\left(\mu \mathrm{mol} \mathrm{min}^{-1} \mathrm{mg}^{-1}\right)\end{array}$ & $R^{2}$ \\
\hline ABTS & methoxy-phenol & Laccase & $21.1 \pm 4.82$ & $5.71 \pm 0.81$ & 0.96 \\
\hline Hydroquinone & para-diphenol & Laccase & $2.05 \pm 0.38$ & $4.37 \pm 0.26$ & 0.79 \\
\hline$p$-Phenylenediamine & non-phenolic & Laccase & $2.01 \pm 0.44$ & $1.73 \pm 0.13$ & 0.93 \\
\hline Syringaldazine & methoxy-phenol & Laccase & $21.2 \pm 8.3$ & $4.51 \pm 0.74$ & 0.82 \\
\hline Caffeic acid & ortho-diphenol & Non-specific & $1.11 \pm 0.43$ & $1.63 \pm 0.62$ & 0.74 \\
\hline DHPPA & meta-diphenol & Non-specific & - & - & - \\
\hline L-DOPA & ortho-diphenol & Non-specific & $0.26 \pm 0.07$ & $1.4 \pm 0.08$ & 0.82 \\
\hline Dopamine & ortho-diphenol & Non-specific & $1.21 \pm 0.32$ & $2.51 \pm 0.18$ & 0.85 \\
\hline 4-Hydroxyanisole & mono-phenol & Tyrosinase & - & - & - \\
\hline Tyramine & mono-phenol & Tyrosinase & - & - & - \\
\hline L-Tyrosine & mono-phenol & Tyrosinase & - & - & - \\
\hline
\end{tabular}

680

681

682

683

684

685

686

687

688

689

690

691 
Accepted; Developmental and Comparative Immunology; $27^{\text {th }}$ April 2020.

692 Table 3 Inhibition of laccase and catecholoxidase activities

\begin{tabular}{lllll}
\hline Inhibitors & Enzyme target & $\begin{array}{l}\text { Inhibitor } \\
\text { conc. }\end{array}$ & \multicolumn{2}{l}{ Inhibition (\%) } \\
\cline { 3 - 5 } & & & Dopamine & Hydroquinone $^{\#}$ \\
\hline Benzoic acid & Non-specific & $0.1 \mathrm{mM}$ & 95.9 & 76.9 \\
& & $0.5 \mathrm{mM}$ & 98.7 & 84.1 \\
& & $1 \mathrm{mM}$ & 100 & 100 \\
Citric acid & Non-specific & $0.1 \mathrm{mM}$ & 87.4 & 71.3 \\
& & $0.5 \mathrm{mM}$ & 88.9 & 78.9 \\
& & $1 \mathrm{mM}$ & 100 & 100 \\
CTAB & Laccase & $0.1 \mathrm{mM}$ & 67 & 98 \\
& & $0.5 \mathrm{mM}$ & 84 & 100 \\
EDTA & & $1 \mathrm{mM}$ & 90.7 & 100 \\
& Non-specific & $0.1 \mathrm{mM}$ & 85.6 & 72.3 \\
& & $0.5 \mathrm{mM}$ & 92.6 & 97.6 \\
4-hexylresorcinol & Catecholoxidase & $0.1 \mathrm{mM}$ & 100 & 100 \\
& \& Tyrosinase & $0.5 \mathrm{mM}$ & 57 & - \\
& & $1 \mathrm{mM}$ & 82.8 & - \\
PTU & Non-specific & $0.1 \mathrm{mM}$ & 84.1 & 93.5 \\
& & $0.5 \mathrm{mM}$ & 89.7 & 98.7 \\
& & $1 \mathrm{mM}$ & 90 & 100 \\
\hline
\end{tabular}

693

694

695

696

697

698

699

700

\#, substrates were used at a standard concentration of $5 \mathrm{mM}$ for all inhibition assays

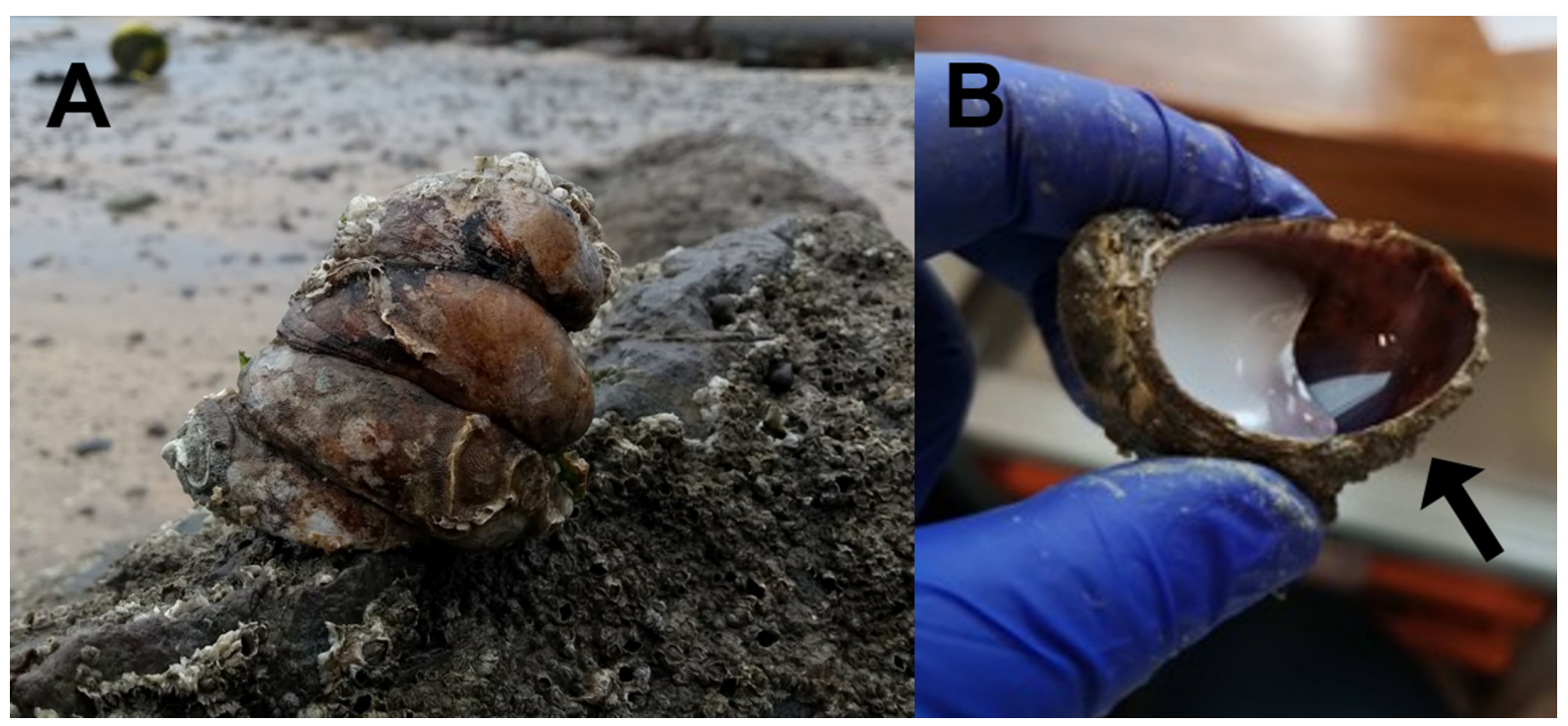

Figure 1. Typical stack formation of Crepidula fornicata (A) and accessibility of haemolymph after (solid) tissue removal (B). Black arrow points to pooled haemolymph at the aperture of the shell. 

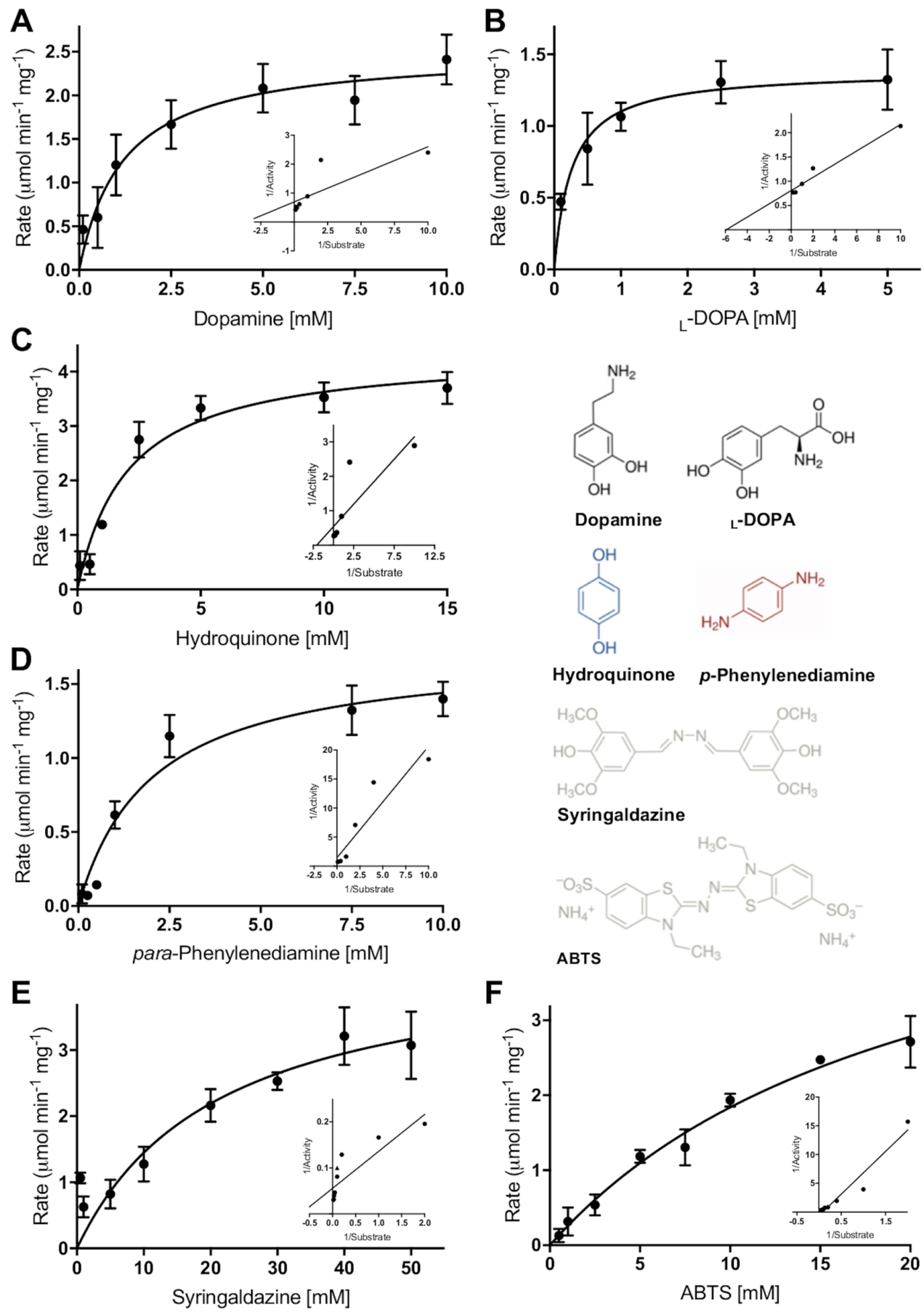

Figure 2. Laccase and catecholoxidase activities of Crepidula fornicata haemolymph protein in the presence of diverse substrates in vitro. Protein $(1 \mathrm{mg}$ $\mathrm{mL}^{-1}$ ) was incubated in the presence of each substrate for 10 minutes. Products derived from the enzymatic oxidation of substrate were observed across several wavelengths (listed in Table 1). Values represent the mean \pm standard error $(n=3$ biological replicates made-up of 3 technical replicates each). Enzyme-substrate kinetics were calculated in GraphPad PRISM v7 using Michaelis-Menten non-linear regression. Each panel also contains the respective double-reciprocal (Lineweaver-

718 Burk) plot. Inset - chemical structures of ortho-diphenols (coloured black), paradiphenol (coloured blue), phenols with methoxy groups (coloured grey), and a nonphenolic substrate (coloured red). 

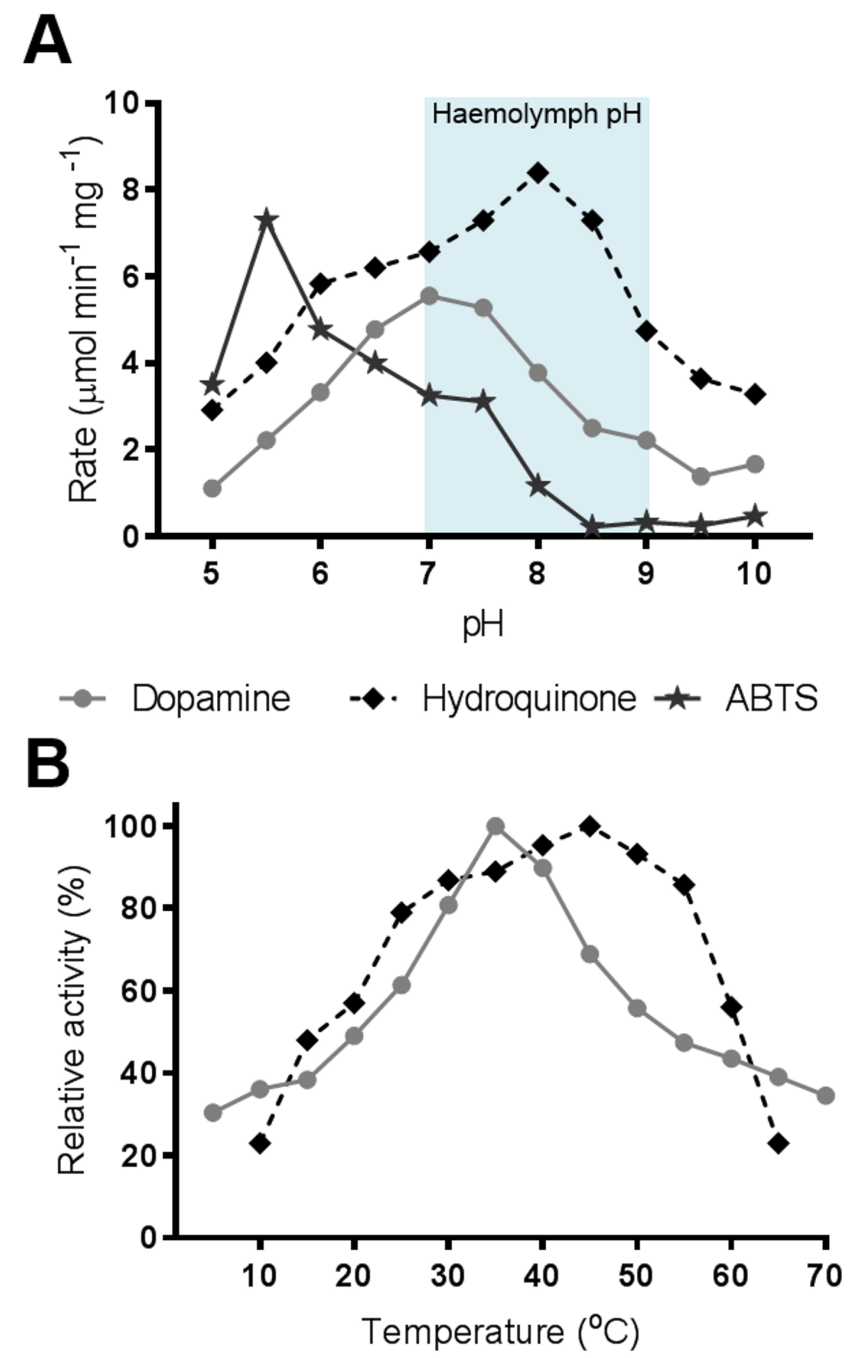

Figure 3. Effect of $\mathrm{pH}$ and temperature on laccase and catecholoxidase activities in the haemolymph of Crepidula fornicata. Protein $\left(1 \mathrm{mg} \mathrm{mL}^{-1}\right)$ was incubated in the presence of either substrate for 10 minutes across the $\mathrm{pH}$ range $5-10(\mathbf{A})$ and the temperature range $5-70^{\circ} \mathrm{C}(\mathrm{B})$. Activity (rate) was measured as the amount of product formed from the oxidation of dopamine (into dopachrome), hydroquinone (into benzoquinone), and $\mathrm{ABTS}$ (into $\mathrm{ABTS}^{+}$). In (A), the $\mathrm{pH}$ range of fresh (ex vivo) limpet haemolymph $(n=141)$ is shaded blue. In $(\mathbf{B})$, values are expressed as a percentage of the mean maximum value for dopamine $\left(35^{\circ} \mathrm{C}\right)$ and hydroquinone $\left(45^{\circ} \mathrm{C}\right)$. 


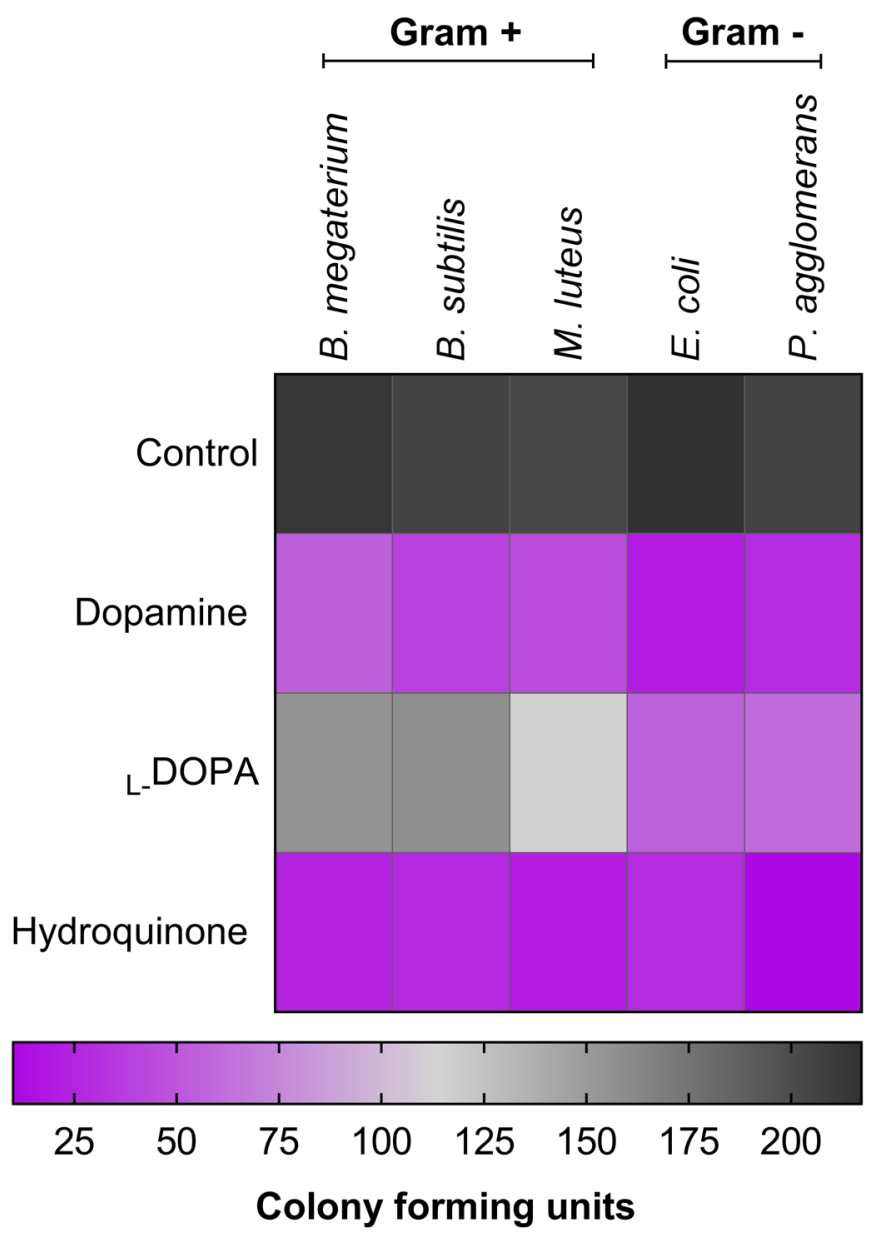

Figure 4. Antibacterial effects of laccase- and catecholoxidase-derived reaction products in vitro. Cell-free haemolymph protein $\left(1 \mathrm{mg} \mathrm{mL}^{-1}\right)$ from Crepidula fornicata was incubated with ortho-diphenolic (dopamine, L-DOPA) and para-diphenolic (hydroquinone) substrates for 10 minutes. Post-incubation, proteins were filtered $(>10$ $\mathrm{kDa}$ cut-off) using centrifugation, and the subsequent reaction mixtures containing the oxidised products were incubated with Gram-positive (B. megaterium, B. subtilis, $M$. luteus) and Gram-negative (E. coli, P. agglomerans) bacteria. The heat map depicts the mean number of colony forming units for treated microbes $(n=3)$ and controls (substrates were omitted). 


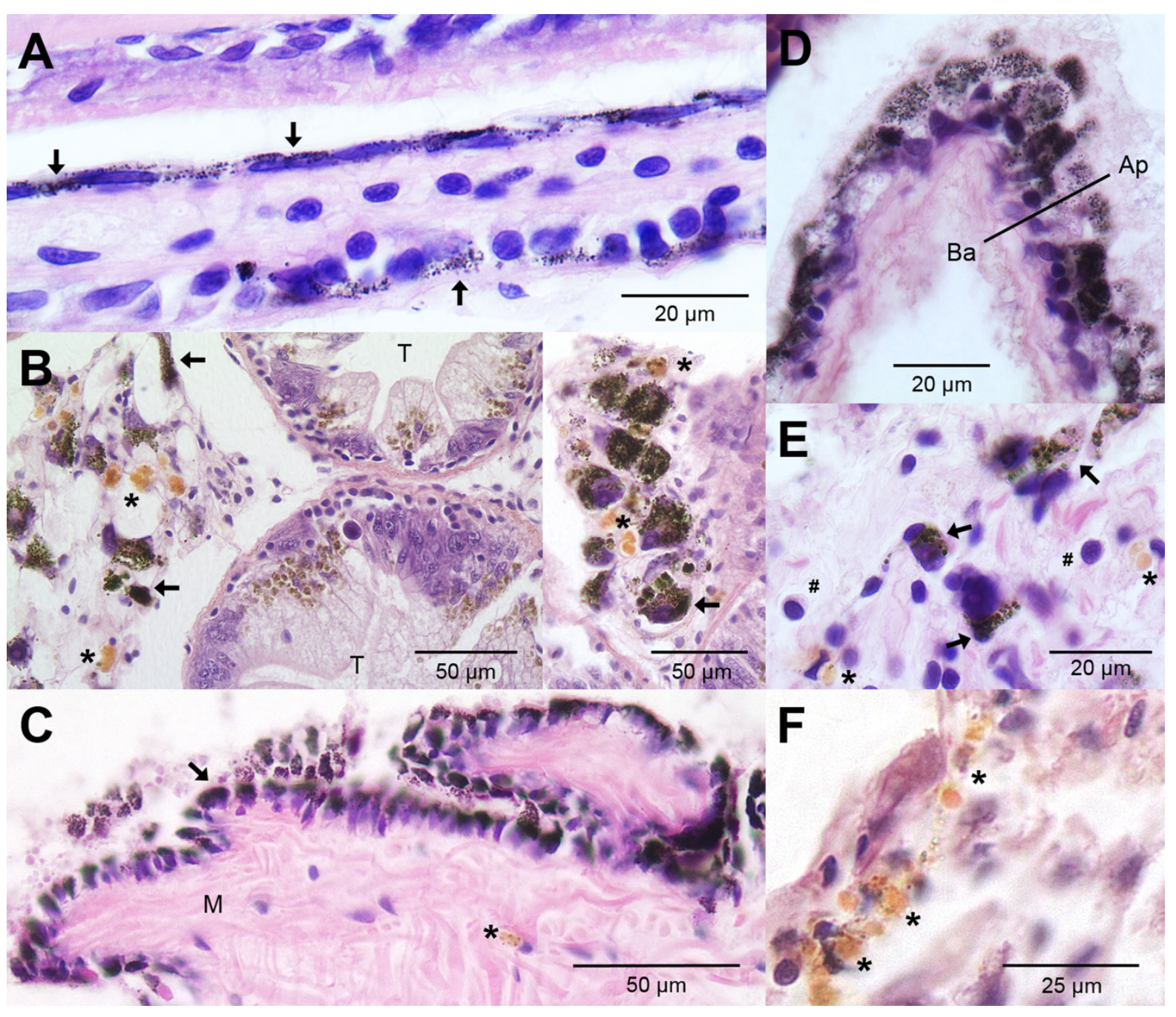

Figure 5. Tissue histology of Crepidula fornicata. Photomicrographs depict transverse sections of gill tissue $(A)$, the digestive gland $(B)$, the foot musculature $(C)$, barrier epithelium (D), and connective tissues ( $E$ and $F$ ). In all images, arrows point to melanin deposits within a variety of cell types, and, each asterisk $\left({ }^{*}\right)$ indicates lipofuscin-like material. Ap, apical; $B a$, basal; $M$, muscle; $T$, tubule. In (E), a hashtag 


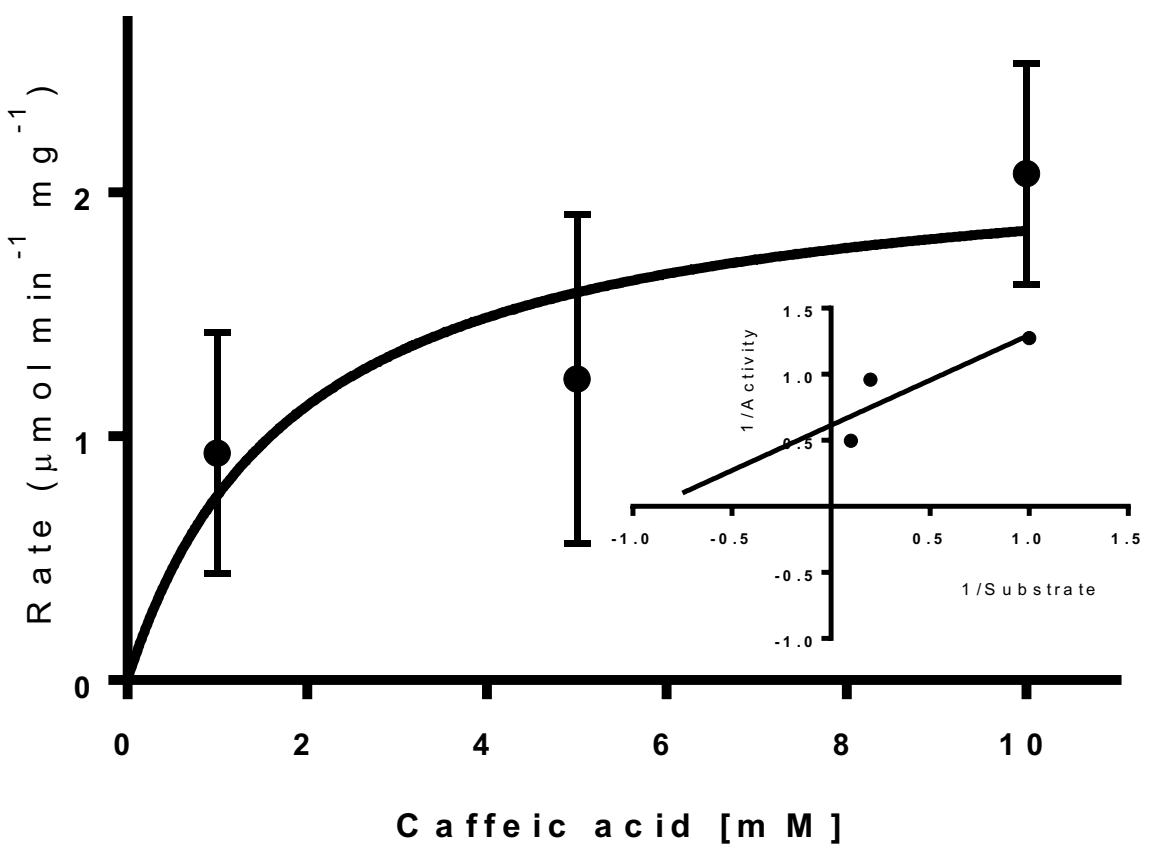<smiles>O=C(O)/C=C/c1ccc(O)c(O)c1</smiles>
haemolymph protein in the presence of caffeic acid in vitro. Protein $\left(1 \mathrm{mg} \mathrm{mL}^{-1}\right)$ was incubated in the presence of substrate for 10 minutes. Products derived from the enzymatic oxidation of substrate were observed at $492 \mathrm{~nm}$. Values represent the mean \pm standard error ( $n=3$ biological replicates made-up of 3 technical replicates each). Enzyme-substrate kinetics were calculated in GraphPad PRISM v7 using MichaelisMenten non-linear regression. The panel also contains the respective double reciprocal (Lineweaver-Burk) plot. Inset - chemical structure caffeic acid. 

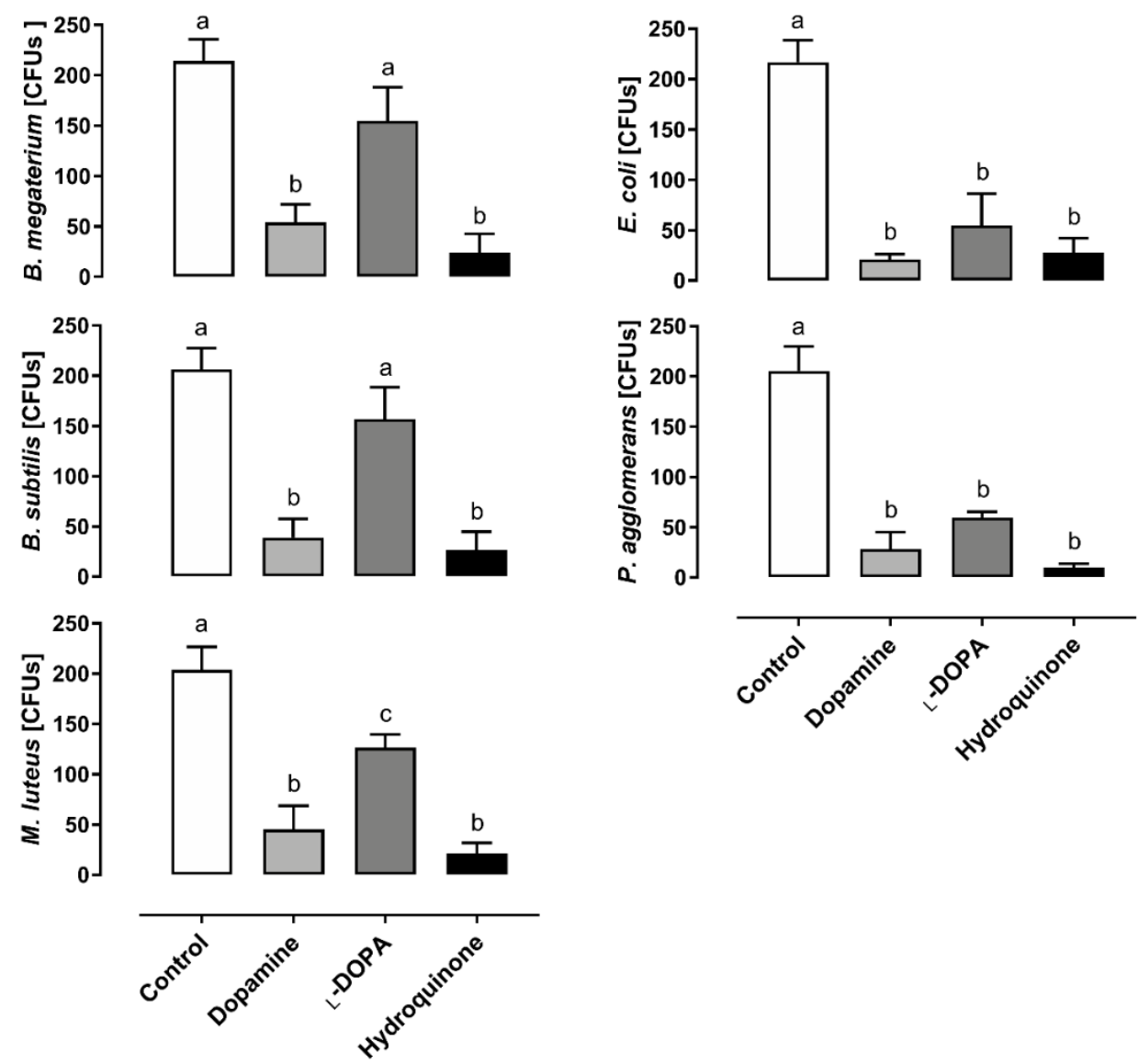

Supplementary Figure 2 Antibacterial effects of laccase- and catecholoxidasederived reaction products in vitro. Cell-free haemolymph protein $\left(1 \mathrm{mg} \mathrm{mL}^{-1}\right)$ from Crepidula fornicata was incubated with ortho-diphenolic (dopamine, L-DOPA) and para-diphenolic (hydroquinone) substrates for 10 minutes. Post-incubation, proteins were filtered (>10 KDa cut-off) using centrifugation, and the subsequent reaction mixtures containing the oxidised products were incubated with Gram-positive ( $B$. megaterium, B. subtilis, M. luteus) and Gram-negative (E. coli, P. agglomerans) bacteria. Unshared letters represent significant differences $(P \leq 0.05)$ - determined by Tukey's multiple comparisons (post hoc). 